\title{
Development of Site Classification System and Modification of Design Response Spectra Considering Geotechnical Characteristics in Korea
}

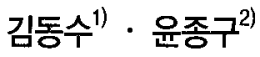 \\ Kim, Dong-Soo $\cdot$ Yoon, Jong-Ku
}

\begin{abstract}
Site response analyses were performed based on equivalent linear technique using shear wave velocity profiles of 162 sites collected around the Korean peninsula. The site characteristics, particularly the shear wave velocities and the depth to the bedrock, are compared to those in the western United States. The results show that the site-response coefficients based on the mean shear velocity of the top $30 \mathrm{~m}\left(\mathrm{~V}_{\mathrm{S} 30}\right)$ suggested in the current code underestimates the motion in short-period ranges and overestimates the motion in mid-period ranges. The current Korean code based on UBC is required to be modified considering site characteristics in Korea for the reliable estimation of site amplification. From the results of numerical estimations, new regression curves were derived between site coefficients $\left(\mathrm{F}_{\mathrm{a}}\right.$ and $\left.\mathrm{F}_{\mathrm{v}}\right)$ and the fundamental site periods, and site coefficients were grouped based on site periods with reasonable standard deviations compared to site classification based on $\mathrm{V}_{\mathrm{S} 30 \text {. Finally, new site }}$ classification system and modification of design response spectra are recommended considering geotechnical characteristics in Korea.
\end{abstract}

Key words Site response analysis, Response spectra, Site coefficient, Site period, Local site condition, Shallow bedrock depth, Site classification system

\section{INTRODUCTION}

The Korean Peninsula belongs to a region of low seismicity located inside the Eurasian plate. Since few earthquake motion data which have substantial magnitude and intensities were recorded in Korea, the design rock-outcrop earthquake ground motion is determined by the seismic hazard map based on historical earthquake records. And the site classification and the corresponding site coefficients were determined similar to the 1994 and 1997 NEHRP Provisions, which are revised based on the results from the investigation of the 1989 Loma Prieta earthquakes in the western United States (NEHRP, 1994,

\footnotetext{
1) 정회원 - 한국과학기술원 건설 및 환경공학과 교수

(대표저자: dskim@kaist.ac.kr)

2) 정회원 · 한국유지관리 주식회사 지반설계사업부 이사

본 논문에 대한 토의롤 2007년 10월 31일가지 학회로 보내 주시면 그 결 과를 게재하겠습니다.
}

(논문접수일 : 2007. 7. 6/ 심사종료일 : 2007. 8. 24)
1997). ${ }^{(1,2)}$ Since site effects are directly dependent on the local site conditions, the use of site coefficients derived from earthquake records which occurred in different site conditions may mislead the earthquake ground motion. Therefore, it is important to compare the local site conditions in Korea to those in the western United States and to assess their effects on site coefficients, for the reliable estimation of earthquake ground motions in Korea.

Many countries use the site characterization system which is based on the soil properties of top $30 \mathrm{~m}$, disregarding the depth of soil to rock if greater than $30 \mathrm{~m}$, the soil properties below $30 \mathrm{~m}$, and the properties of the rock underlying the soil (NEHRP, 1997) ${ }^{(2)}$, (ICBO, 1997) ${ }^{(3)}$, $(\mathrm{CEN}, 2001)^{(4)}$, (MOCT, 1997) ${ }^{(5)}$. Site classification based on the mean shear wave velocity of the top $30 \mathrm{~m}\left(\mathrm{~V}_{\mathrm{S} 30}\right)$ are unambiguous, practical to use and scientifically sound because shear wave velocity is clearly measurable in the field by geophysical techniques, thus removing the 
ambiguity of definitions of site categories contained in previous codes. The top $30 \mathrm{~m}$ soil certainly play a role in local site response, the restriction to the top $30 \mathrm{~m}$ makes it much more feasible for geotechnical engineers to come up with the necessary information for the site from available data in the region of deep bedrock depth (MCEER, 1999). ${ }^{(6)}$

In Korea, bedrocks are mostly located at the depth less than $30 \mathrm{~m}$ from the ground surface and $V_{\mathrm{S} 30}$ is usually calculated fallaciously by extrapolating the $V_{S}$ of bedrock to $30 \mathrm{~m}$. Thus, it is affected by the stiffness of bedrock and $V_{\mathrm{S} 30}$ is usually increased if the bedrock depth is shallower than $30 \mathrm{~m}$. In the regions of shallow bedrock, most of the site investigations are performed up to bedrock and the bedrock depth is clearly defined and the shear wave velocities of soil layers and bedrock are mostly determined for seismic ground response analysis. Therefore, both soil stiffness and bedrock depth which are meaningful parameters in the site response, can be easily considered in the site classification instead of $V_{\mathrm{S} 30}$ in the regions of shallow bedrock.

In this paper, the shear wave velocity profiles were collected at 162 sites around the Korean Peninsula. The sites were categorized as $\mathrm{S}_{\mathrm{B}}, \mathrm{S}_{\mathrm{C}}, \mathrm{S}_{\mathrm{D}}$ and $\mathrm{S}_{\mathrm{E}}$ based on $\mathrm{V}_{\mathrm{S} 30}$ (MOCT, 1997). ${ }^{(5)}$ The site characteristics, particularly shear wave velocities and bedrock depth, were compared to those in the western United States. Ground response analyses were performed at 162 sites using one-dimensional equivalent linear analysis at the acceleration levels of $0.110 \mathrm{~g}$, $0.154 \mathrm{~g}$, and $0.220 \mathrm{~g}$ which correspond to the Collapse Level Earthquake (CLE) for seismic category II, I and special structures, respectively, in Korean seismic design guideline. The evaluated site response spectra and the corresponding short-period and long-period site coefficients were compared to those in 1997 NEHRP provisions, and the differences in the site response were assessed considering local site conditions in Korea. New regression curves were derived between site coefficients $\left(F_{a}\right.$ and $\left.F_{v}\right)$ and the fundamental site periods. Finally, new site classification system were evaluated and corresponding site coefficients and the design response spectra for new site classes were tentatively suggested.

\section{GEOLOGICAL SITE CONDITIONS IN KOREA AND THE WESTERN UNITED STATES}

\subsection{Shear Wave Velocities Profiles}

In order to assess the local site conditions in Korea, the shear wave velocity $\left(\mathrm{V}_{\mathrm{S}}\right)$ profiles were collected at 162 sites all around the Korean Peninsula, particularly at urban areas and large construction sites, as shown in Fig. 1. Among 162 sites as shown in Table 1, 16, 76, 60, and 10 sites were classified as $\mathrm{S}_{\mathrm{B}}, \mathrm{S}_{\mathrm{C}}, \mathrm{S}_{\mathrm{D}}$, and $\mathrm{S}_{\mathrm{E}}$, respectively, according to the Korean seismic guideline based on $V_{S 30}$ using equation (1) (MOCT, 1997). ${ }^{(5)}$

$$
V_{S 30}=30 / \sum_{i=1}^{n} \frac{d_{i}}{V_{S i}}
$$

where $d_{i}$ is the thickness of each soil layer, $V_{s i}$ is the shear wave velocity of each soil layer and $n$ is number of soil layers.

Generally, most of $\mathrm{S}_{\mathrm{B}}, \mathrm{S}_{\mathrm{C}}$ and $\mathrm{S}_{\mathrm{D}}$ sites consist of 5 types of geotechnical layers including fill and alluvial soil in the upper layer and weathered residual soil, weathered rock, soft rock or hard rock as a bedrock. The shear wave velocity profiles in the soil layers for all soil types are shown in Fig. 2.

The ranges of depth to bedrock are $0.0 \mathrm{~m}$ to $-14.0 \mathrm{~m}$, $-5.3 \mathrm{~m}$ to $-50.0 \mathrm{~m},-9.25 \mathrm{~m}$ to $-47.0 \mathrm{~m}$, and $-29.0 \mathrm{~m}$ to

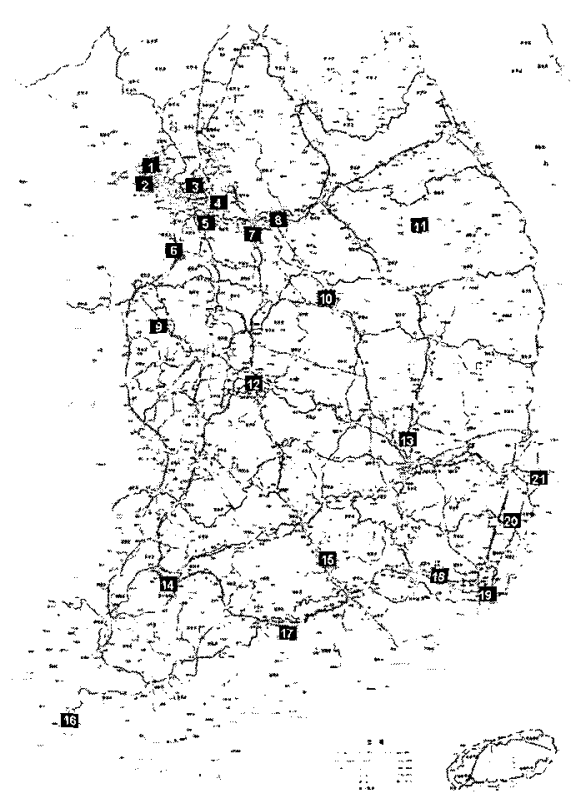

〈Figure 1) Sites used in this study around the Korean peninsula. 
(Table i) Site Locations and Investigation Methods

\begin{tabular}{|c|c|c|c|c|}
\hline Site & Site Location & \multicolumn{2}{|c|}{ Number of Sites } & Investigation method ${ }^{* *}$ \\
\hline Subway \#1 & $3,12,19$ & \multicolumn{2}{|c|}{8} & SPT \\
\hline Subway \#2 & 3 & \multicolumn{2}{|c|}{8} & $\mathrm{D}$ \\
\hline Apartment & $1,3,5,6,13,15,16,19$ & \multicolumn{2}{|c|}{34} & SPT \\
\hline \multirow{3}{*}{ Long Bridge ${ }^{* * *}$} & \multirow{3}{*}{7,14} & \multirow{3}{*}{11} & 3 & $\mathrm{D}$ \\
\hline & & & 5 & $\mathrm{~S}$ \\
\hline & & & 3 & $\mathrm{SASW}+\mathrm{S}$ \\
\hline Port & $2,17,19$ & \multicolumn{2}{|c|}{23} & $S$ \\
\hline \multirow{9}{*}{ Urban area ${ }^{* *}$} & \multirow{4}{*}{9} & \multirow{4}{*}{18} & 12 & SASW \\
\hline & & & 1 & $\mathrm{D}$ \\
\hline & & & 2 & D+SASW \\
\hline & & & 3 & $\mathrm{C}+\mathrm{D}+\mathrm{SASW}$ \\
\hline & \multirow{5}{*}{21} & \multirow{5}{*}{29} & 17 & SASW \\
\hline & & & 1 & $\mathrm{D}$ \\
\hline & & & 1 & $\mathrm{C}+\mathrm{D}$ \\
\hline & & & 7 & D+SASW \\
\hline & & & 3 & $\mathrm{C}+\mathrm{D}+\mathrm{SASW}$ \\
\hline \multirow{2}{*}{ Rail road ${ }^{* * *}$} & \multirow{2}{*}{11,18} & \multirow{2}{*}{17} & 16 & $\mathrm{D}$ \\
\hline & & & 1 & SPS \\
\hline Highway & 8,10 & \multicolumn{2}{|c|}{5} & $\mathrm{D}$ \\
\hline Road & $4,7,8,20$ & \multicolumn{2}{|c|}{9} & $\mathrm{D}$ \\
\hline \multicolumn{2}{|r|}{ Total } & \multicolumn{3}{|c|}{162} \\
\hline
\end{tabular}

${ }^{*}$ Number is marked on the map in Fig. 1.

* STP, C, D, S and SASW represent the Standard Penetration Test, Crosshole test, Downhole test, SPS logging test and SASW test, respectively.

**** Two or three site investigation methods were used simultaneously for site location 7, 9, 14 and 21 . In those cases, representative shear wave velocity profiles were used to SHAKE analysis.

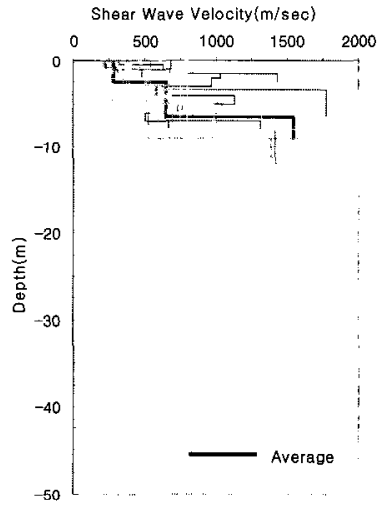

(a) Soil Type $S_{B}$

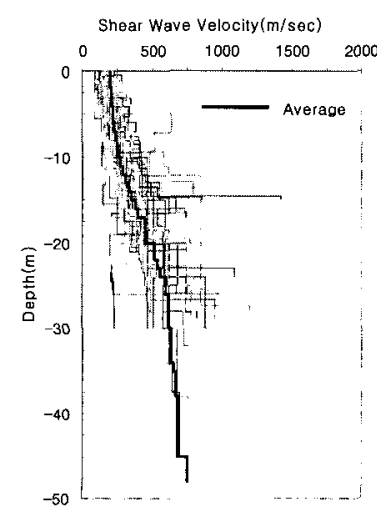

(c) Soil Type $S_{D}$

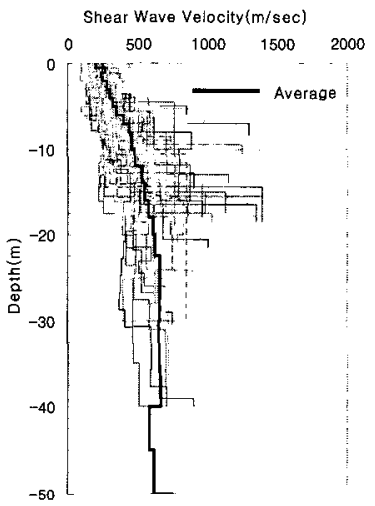

(b) Soil Type $S_{c}$

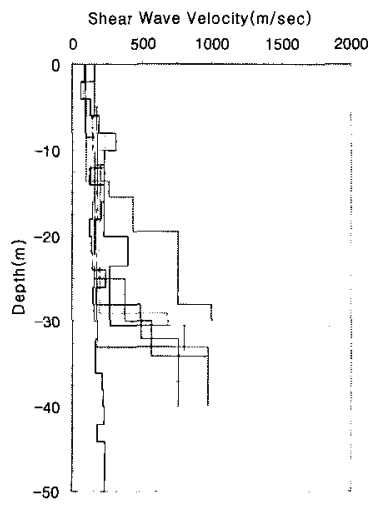

(d) Soil Type $\mathrm{S}_{\mathrm{E}}$

〈Figure 2) Shear wave velocity profiles.

$-56.0 \mathrm{~m}$ at $\mathrm{S}_{\mathrm{B}}, \mathrm{S}_{\mathrm{C}}, \mathrm{S}_{\mathrm{D}}$ and $\mathrm{S}_{\mathrm{E}}$ sites, respectively, as shown in Table 2. Also, it is observed that the average depth to bedrock is $-6.0 \mathrm{~m},-18.3 \mathrm{~m},-23.5 \mathrm{~m}$ and $-38.5 \mathrm{~m}$ for $\mathrm{S}_{\mathrm{B}}, \mathrm{S}_{\mathrm{C}}$, $S_{D}$ and $S_{E}$ sites, respectively, showing that the depth of most of bedrocks is less than $30 \mathrm{~m}$ except $\mathrm{S}_{\mathrm{E}}$ sites.

The shear wave velocity profiles of the ROSRINE sites are shown in Fig. 3 (Bardet et al., 2001). ${ }^{(7)}$ The bedrocks of the ROSRINE sites are located very deep and the range of bedrock depth is wide. Some of them are extended to the depth over $100 \mathrm{~m}$ to $300 \mathrm{~m}$. Therefore, it can be postulated that the bedrock depth cannot be adopted in the site classification and $\mathrm{V}_{\mathrm{S} 30}$ is used for practical purpose in the western United States. In Korea, however, most of bedrocks are located at shallower depth than $30 \mathrm{~m}$, and $V_{\mathrm{S} 30}$ is usually calculated fallaciously by extrapolating the $V_{S}$ of bedrock to $30 \mathrm{~m}$, except for $\mathrm{S}_{\mathrm{E}}$ sites. This is the most notable difference in geotechnical soil profile characteristics between Korea and the western United States.

\subsection{Site Periods}

Difference is more obvious when the site period of 
〈Table 2〉 Depth to bedrock, $V_{\mathrm{S} 30}$, and Site periods in each category

\begin{tabular}{|c|c|c|c|c|c|c|c|c|c|c|c|c|c|}
\hline & & \multicolumn{3}{|c|}{$\mathrm{S}_{\mathrm{B}}$} & \multicolumn{3}{|c|}{$\mathrm{S}_{\mathrm{C}}$} & \multicolumn{3}{|c|}{$S_{D}$} & \multicolumn{3}{|c|}{$\mathrm{S}_{\mathrm{E}}$} \\
\hline & & Min & Max & Ave & Min & Max & Ave & Min & $\operatorname{Max}$ & Ave & Min & Max & Ave \\
\hline \multicolumn{2}{|c|}{ Depth to Bedrock (m) } & 0.0 & -14.0 & -6.0 & -5.3 & -50 & -18.3 & -9.3 & -47 & -23.5 & -28 & -56. & -39 \\
\hline \multicolumn{2}{|c|}{$\mathrm{V}_{\mathrm{s} 30}(\mathrm{~m} / \mathrm{sec})$} & 761 & 1245 & 961 & 374 & 730 & 489 & 192 & 370 & 312.7 & 134 & 179 & 166 \\
\hline \multirow[b]{2}{*}{$\mathrm{T}^{* *}$} & Korea & 0.0 & 0.10 & 0.06 & 0.07 & 0.42 & 0.22 & 0.24 & 0.67 & 0.37 & 0.68 & 1.35 & 0.88 \\
\hline & WUS* & \multicolumn{3}{|c|}{ - } & \multicolumn{2}{|c|}{$0.30-0.80$} & $\begin{array}{c}\text { About } \\
0.50\end{array}$ & \multicolumn{2}{|c|}{$0.40-1.90$} & $\begin{array}{c}\text { About } \\
1.20\end{array}$ & \multicolumn{3}{|c|}{-} \\
\hline
\end{tabular}

* Used the data at http://goeinfo.usc.edu/rosrine, WUS means the Western United States.

${ }^{* *} \mathrm{~T}=$ Site Period

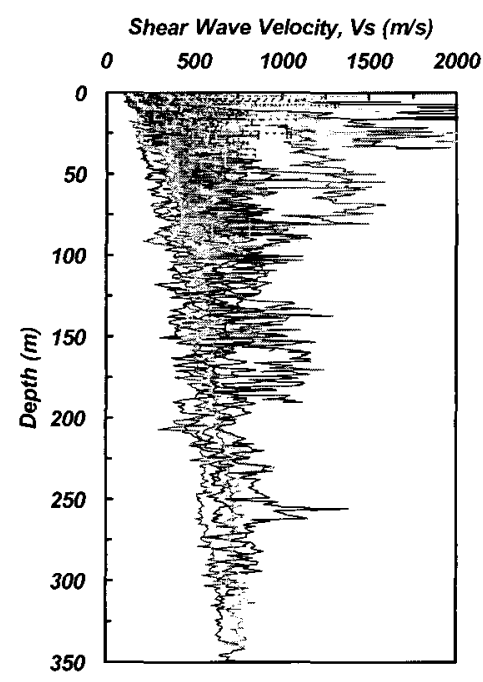

(Figure 3) Shear wave velocity profiles of the ROSRINE sites.

Korean sites are compared with those of ROSRINE sites. The natural site periods can be directly calculated from the fundamental site frequency or period where the resonance of ground motions is mainly generated at a site during earthquake. The characteristic site period $\mathrm{T}$, which is dependent on both the shear wave velocity and layer thickness is computed by:

$$
T=4 \sum_{i=1}^{n} \frac{d_{i}}{v_{s i}}
$$

where $d_{i}$ is the thickness of each soil layer above the bedrock, $V_{s i}$ is the shear wave velocity of each soil layer, and $n$ is number of soil layers up to bedrock.

The natural site periods by Equation (2) are in the range of 0.07 and $0.42 \mathrm{sec}, 0.27$ and $0.67 \mathrm{sec}$, at $S_{C}$ and $\mathrm{S}_{\mathrm{D}}$ sites, respectively. The average site periods are 0.22 and 0.37 at $S_{C}$ and $S_{D}$ sites, respectively, which is much lower than $0.5 \mathrm{sec}$. The site periods $\mathrm{T}$, which are calculated using the collected ROSRINE data are compared with those of this study in Table 2.

To investigate the distribution of site periods of the Korean sites compared to ROSEINE sites, the probabilistic distributions of site period were illustrated in Fig. 4 (Sun, 2004). ${ }^{(8)}$ It was assumed that the site periods follow the Gaussian distribution function. The probability of site periods within the distribution curve is equal to $68 \%$ in \pm one standard deviation $(\sigma)$ and to $95 \%$ in $\pm 2 \sigma$. As shown in Fig. 4, site periods $\mathrm{T}$ of the western United States are much higher than those of the Korea at both the site class $S_{C}$ and $S_{D}$. It is also observed that the range of site periods of Korean sites is much narrower than those of the ROSRINE sites for both the $S_{C}$ and $S_{D}$ sites.

These differences in geotechnical site conditions such as the soil stiffness and the depth to bedrock between the western United States and Korea, can result in different site response characteristics, particularly amplification period's range in the response spectrum. Therefore, although sites in two different regions are classified as the same categories based on $V_{\mathrm{S} 30}$, the seismic responses can be different and it is required to reevaluate the site responses in Korea for the reliable estimation of earthquake ground motion.

\section{SITE RESPONSE ANALYSES}

Site response analyses were performed using SHAKE program to estimate the site-specific earthquake ground motions at 162 sites around the Korean Peninsula (Schnabel et al., 1972 $2^{(9)}$; Idriss and Sun, 1991 ${ }^{(10)}$ ). Main objective of this study is to examine the rationality of the current site coefficients in Korean seismic guideline 


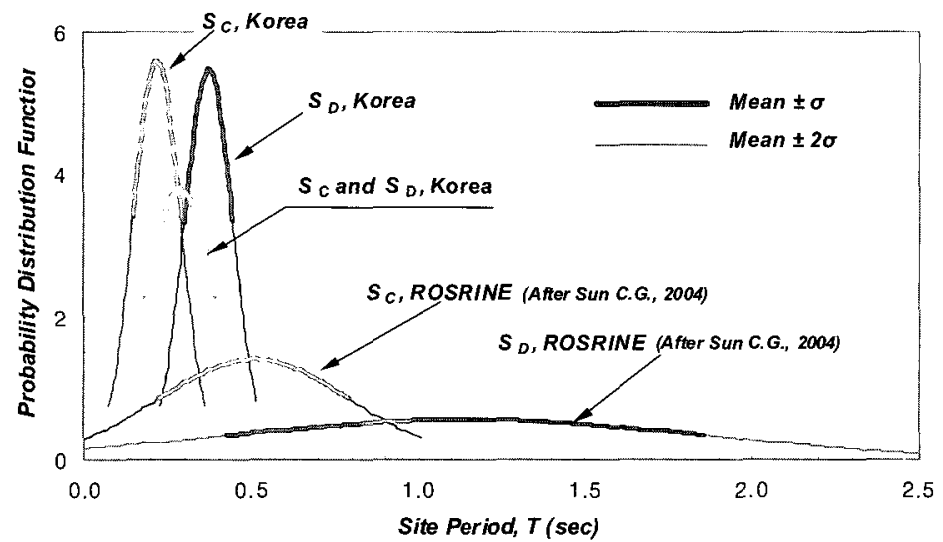

$\langle$ ifigure $b$ Probability distribution functions of the site classes with Site Periods.

〈Jejla 3) Earthquake Record Information

\begin{tabular}{c|c|c|c|c}
\hline Earthquake & Magnitude & Recorded Date & Recorded Location & Site Category \\
\hline Artificial & - & - & - & $\mathrm{S}_{\mathrm{B}}$ \\
\hline Hacinohe & 7.9 & $05 / 16 / 68$ & Tokachioki, Japan & $\mathrm{S}_{\mathrm{C}}$ \\
\hline Ofunato & 7.4 & $12 / 06 / 78$ & Miyagikenoki, Japan & $\mathrm{S}_{\mathrm{D}}$ \\
\hline El Centro & 5.2 & $15 / 10 / 79$ & California, USA & $\mathrm{S}_{\mathrm{C}}$ \\
\hline Kocaeli & 7.4 & $17 / 08 / 99$ & Kocaeli, Turkey & $\mathrm{S}_{\mathrm{A}}$ \\
\hline Kobe & 6.9 & $16 / 01 / 95$ & Kobe, Japan & $\mathrm{S}_{\mathrm{B}}$ \\
\hline Friuli & 6.5 & $16 / 05 / 76$ & Friuli, Italy & $\mathrm{S}_{\mathrm{B}}$ \\
\hline ChiChi & 7.6 & $20 / 09 / 99$ & ChiChi, Taiwan & $\mathrm{S}_{\mathrm{A}}$ \\
\hline San Fernando & 6.6 & $09 / 02 / 71$ & California, USA & $\mathrm{S}_{\mathrm{A}}$ \\
\hline
\end{tabular}

because the coefficients are based on UBC 1997 developed considering site characteristics in the western United States that are quite different from those in the Korean Peninsula, as discussed before.

The design rock-outcrop accelerations are $0.110 \mathrm{~g}$, $0.154 \mathrm{~g}$ and $0.220 \mathrm{~g}$ which correspond return period 500 years, 1,000 years and 2,400 years, respectively, based on Korean seismic design guideline. Due to the paucity of strong-motion records for earthquakes in Korea, nine earthquake accelerograms suggested by PEER (Pacific Earthquake Engineering Research) were selected to consider various frequency contents of earthquake motions in the analyses [http://peer.berkeley.edu/smcat/ search. html]. These input earthquake motions are listed in Table 5. The levels of the input rock-outcrop accelerations were modified to the levels in this study. Therefore, a total of 4,374 runs (1,458 runs for each return period) are perfor med for $S_{B}, S_{C}, S_{D}$ and $S_{E}$ site categories. The nonlinear soil properties of various soils, expressed as $G / G_{\max }$ reduction and damping curves, were determined by laboratory tests for soil deposits where the soil specimen were acquired at site locations or by using database in Korea collected by Kim and Choo $(2001)^{(11)}$ when test results were not available.

\section{RESULTS OF SITE RESPONSE ANALYSES}

\subsection{Response Spectra}

The evaluated response spectra with 5\% damping ratio together with the mean and +10 of all sites were compared to the spectrum specified in the Korean seismic design guideline for return period 1,000 years (rockoutcrop motion $=0.154 \mathrm{~g}$ ) in Fig. 5 .

In the case of $S_{B}$ sites, the mean $+1 \sigma$ of spectral acceleration from analyses in the building periods up to $0.2 \mathrm{sec}$ is higher than the design response spectrum, but in the building periods above $0.2 \mathrm{sec}$, spectral accelerations are similar to those in the design spectrum. Because the response spectrum below $0.1 \mathrm{sec}$ is not usually considered in the calculation of short-period site coefficient, it can be mentioned that the difference between the 


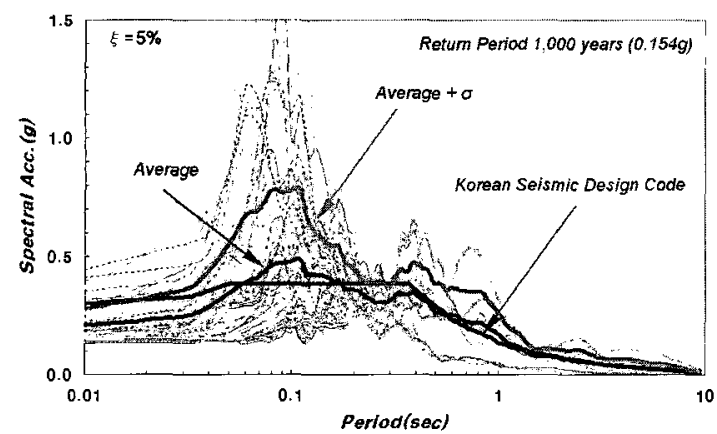

(a) Soil Type $S_{B}$

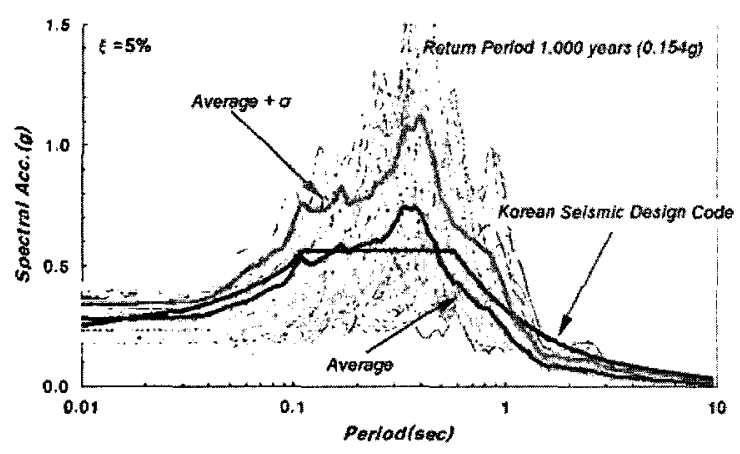

(c) Soil Type $\mathrm{S}_{\mathrm{C}}$

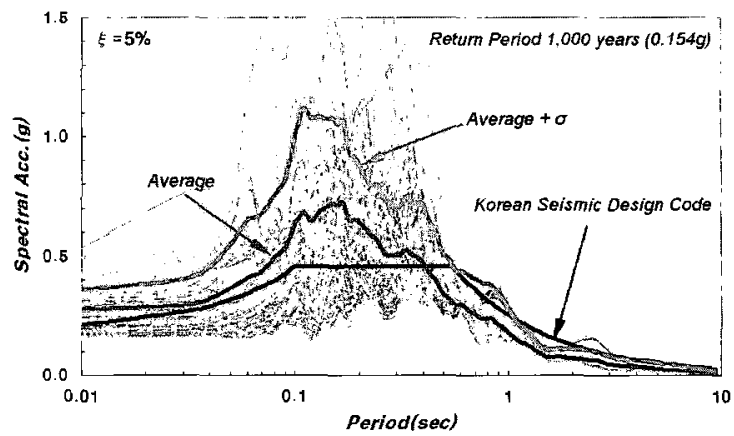

(b) Soil Type $\mathrm{S}_{\mathrm{C}}$

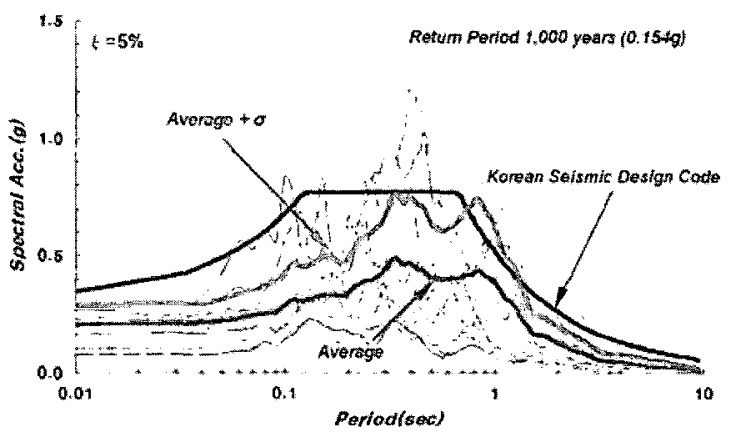

(d) Soil Type $\mathrm{S}_{\mathrm{D}}$

〈Figure 5) Evaluated Response Spectra for return period 1,000 years.

evaluated spectrum and the code is not significant.

Average spectral accelerations on ground surface in period range of 0.10 to $0.45 \mathrm{sec}$ and 0.20 to $0.45 \mathrm{sec}$ at the cases of site classes $S_{C}$ and $S_{D}$, respectively, are significantly amplified than those in the design response spectrum. At a mid or long period above about $0.5 \mathrm{sec}$, however, both estimated spectral accelerations for site classes $S_{C}$ and $S_{D}$ are much lower than those in the design spectrum. It is interesting to note that the significant amplified period ranges are notably consistent with the ranges of the site periods in Table 2 , because the amplification characteristics result from the resonant characteristics of sites corresponding to the site period. Other rock shaking level (other return periods) results were similar to the case of return period 1,000 years.

In the case of $\mathrm{S}_{\mathrm{E}}$ sites, the mean $+1 \sigma$ of spectral acceleration are less than the design response spectrum in almost whole period ranges, except in the range of 0.80 to $1.0 \mathrm{sec}$ which is average site period ranges of $S_{\mathrm{E}}$ sites listed in Table 2. In this case, the design response spectrum in the code overestimates the amplification of response spectra at the short period range.
There are remarkable differences between the current code and the analysis results. The average spectral accelerations of $\mathrm{S}_{\mathrm{B}}, \mathrm{S}_{\mathrm{C}}$ and $\mathrm{S}_{\mathrm{D}}$ sites are significantly amplified in the short-period ranges $(0.2 \sim 0.45 \mathrm{sec})$ and those are substantially smaller than code values in the mid- and long-period ranges (above $0.5 \mathrm{sec}$ ). However, average spectral accelerations obtained by site specific analyses in the $\mathrm{S}_{\mathrm{E}}$ sites are reasonably consistent with the current code

\subsection{Site Coefficients}

Current site classification system and coefficients in Korean seismic design guideline are almost identical to those in the 1994 and 1997 NEHRP provisions, despite the quite differences in local geologic conditions. The site coefficients have been calculated using ratio of response spectra (RRS) or ratio of Fourier spectra (RFS) of the soil and corresponding rock records, and $F_{a}$ and $F_{v}$ using ratio of response spectra are presented in equations (3) and (4) (Dobry et al., 1999). ${ }^{(12)}$ In this study, RRS were used to define $F_{a}$ and $F_{v}$. 


$$
\begin{aligned}
& \mathrm{F}_{\mathrm{a}}(\mathrm{RRS})=\frac{R_{\text {soil }}}{R_{\text {rock }}} \frac{1}{0.4} \int_{0.1}^{0.5} \frac{\mathrm{RS}_{\text {soil }}(T)}{\mathrm{RS}_{\text {rock }}(T)} d T \\
& \mathrm{~F}_{\mathrm{v}}(\mathrm{RRS})=\frac{R_{\text {soil }}}{R_{\text {rock }}} \frac{1}{1.6} \int_{0.4}^{2.0} \frac{\mathrm{RS}_{\text {soil }}(T)}{\operatorname{RS}_{\text {rock }}(T)} d T
\end{aligned}
$$

where $R S_{\text {soil }}$ and $R S_{\text {rock }}$ are response spectra on soil and rock at a given period $\mathrm{T}$, and $R_{\text {soil }}$ and $R_{\text {rock }}$ are the hypocentral distances of soil and rock stations. The ratio of $R_{\text {soill }} / R_{\text {rock }}$ was assumed to be 1.0 in this study.

Estimates of $F_{a}$ and $F_{v}$ have been derived recently by a number of investigators using a variety of databases and procedures. According to Dobry et al. (1999) ${ }^{(12)}$, the site coefficients $F_{a}$ specified in the NEHRP Provisions are about the average value and the site coefficients $F_{v}$ are approximately the average $+1 \sigma$ values. In order to effectively compare site coefficient with NEHRP Provisions, $F_{a}$ is determined as the average value of RRS over the short-period band $0.1-0.5 \mathrm{sec}$ and $F_{v}$ is determined as the average $+1 \sigma$ of RRS over the long-period band $0.4-2.0 \mathrm{sec}$ (Dobry et al., 1999). ${ }^{(12)}$

The RRS of $S_{B}, S_{C}, S_{D}$ and $S_{E}$ sites and the estimated site coefficients $F_{a}$ and $F_{v}$ are shown in Fig. 6 for the earthquake of return period 1,000 years. In the case of $\mathrm{S}_{B}$ sites, RRS values are generally close to 1.0 at site periods above $0.2 \mathrm{sec}$. Short-period site coefficient $\left(F_{a}\right)$ is 1.13 that is little higher than the code value and the long-period site coefficients $\left(F_{v}\right)$ determined based on the average $+1 \sigma$ is 1.01 almost same as the code. In the case of $\mathrm{SC}$ sites, $\mathrm{F}_{\mathrm{a}}$ value on the code is underestimated and $F_{v}$ value is overestimated compared with RRS values in this study. In the case of $S_{D}$ sites, $F_{a}$ value based on the code is also underestimated, and in long period range, $F_{V}$ value based on the code is too overestimated when compared with RRS of $S_{D}$ sites at the study areas in Korea. Especially, there is nearly no amplification in the period range of 1 to $2 \mathrm{sec}$. In the current code, $F_{v}$ is larger than $F_{a}$ at $S_{C}$ and $S_{D}$ sites whereas in this study $F_{a}$ is larger than $F_{v}$ at $S_{C}$ and $S_{D}$ sites, which is totally opposite to the trend in the current codes. These phenomena occur due to the difference of local geologic conditions such as the bedrock depth and site periods. However, in the case of $S_{E}$ sites, $F_{a}$ is smaller than $F_{v}$ and remarkable amplification is occurred in the long period range, which is consistent with the trend in the current codes. The results of the other cases of rock shaking intensities are similar to the case of return period 1,000 years as listed in Table 4 and Table 5.

\begin{tabular}{|c|c|c|c|c|c|c|c|c|c|}
\hline \multirow{3}{*}{$\begin{array}{c}\text { Site } \\
\text { Category }\end{array}$} & \multicolumn{3}{|c|}{$0.110 \mathrm{~g}$} & \multicolumn{3}{|c|}{$0.154 \mathrm{~g}$} & \multicolumn{3}{|c|}{$0.220 \mathrm{~g}$} \\
\hline & \multicolumn{2}{|c|}{ This Study } & \multirow{2}{*}{$\begin{array}{c}\text { NEHRP } \\
1997\end{array}$} & \multicolumn{2}{|c|}{ This Study } & \multirow{2}{*}{$\begin{array}{c}\text { NEHRP } \\
1997\end{array}$} & \multicolumn{2}{|c|}{ This Study } & \multirow{2}{*}{$\begin{array}{c}\text { NEHRP } \\
1997\end{array}$} \\
\hline & $F_{a}$ & $\sigma^{*}$ & & $\mathrm{~F}_{\mathrm{a}}$ & $\sigma$ & & $\mathrm{F}_{\mathrm{a}}$ & $\sigma$ & \\
\hline $\mathrm{S}_{\mathrm{B}}$ & 1.09 & 0.077 & 1.00 & 1.10 & 0.084 & 1.00 & 1.11 & 0.095 & 1.00 \\
\hline $\mathrm{S}_{\mathrm{C}}$ & 1.69 & 0.345 & 1.20 & 1.72 & 0.351 & 1.20 & 1.77 & 0.390 & 1.20 \\
\hline $\mathrm{S}_{\mathrm{D}}$ & 2.09 & 0.438 & 1.58 & 2.05 & 0.448 & 1.50 & 1.98 & 0.499 & 1.36 \\
\hline $\mathrm{S}_{\mathrm{E}}$ & 1.52 & 0.579 & 2.42 & 1.37 & 0.573 & 2.07 & 1.21 & 0.559 & 1.54 \\
\hline
\end{tabular}

(Table d) Comparison of Site Coefficients for short-period $F_{a}$

* $\sigma$ means the standard deviation of $F_{a}$ by Eq. (3)

\begin{tabular}{|c|c|c|c|c|c|c|c|c|c|c|c|c|}
\hline \multirow{3}{*}{$\begin{array}{c}\text { Site } \\
\text { Category }\end{array}$} & \multicolumn{4}{|c|}{$0.110 \mathrm{~g}$} & \multicolumn{4}{|c|}{$0.154 \mathrm{~g}$} & \multicolumn{4}{|c|}{$0.220 \mathrm{~g}$} \\
\hline & \multicolumn{3}{|c|}{ This Study } & \multirow{2}{*}{$\begin{array}{c}\text { NEHRP } \\
1997\end{array}$} & \multicolumn{3}{|c|}{ This Study } & \multirow{2}{*}{$\begin{array}{c}\text { NEHRP } \\
1997\end{array}$} & \multicolumn{3}{|c|}{ This Study } & \multirow{2}{*}{$\begin{array}{c}\text { NEHRP } \\
1997\end{array}$} \\
\hline & Ave." & $\sigma$ & $\mathrm{F}_{\mathrm{v}}^{* *}$ & & Ave. & $\sigma$ & $F_{v}$ & & Ave. & $\sigma$ & $F_{v}$ & \\
\hline $\mathrm{S}_{\mathrm{B}}$ & 1.01 & 0.006 & 1.01 & 1.00 & 1.01 & 0.006 & 1.01 & 1.00 & 1.01 & 0.007 & 1.02 & 1.00 \\
\hline $\mathrm{S}_{\mathrm{C}}$ & 1.09 & 0.085 & 1.17 & 1.69 & 1.10 & 0.096 & 1.19 & 1.65 & 1.12 & 0.122 & 1.24 & 1.58 \\
\hline $\mathrm{S}_{\mathrm{D}}$ & 1.34 & 0.273 & 1.61 & 2.36 & 1.37 & 0.277 & 1.64 & 2.14 & 1.40 & 0.269 & 1.67 & 1.92 \\
\hline $\mathrm{S}_{\mathrm{E}}$ & 2.19 & 0.351 & 2.54 & 3.47 & 2.12 & 0.375 & 2.50 & 3.34 & 2.02 & 0.443 & 2.46 & 3.14 \\
\hline
\end{tabular}

〈Tabla 5) Comparison of Site Coefficients for long-period $F_{v}$ of arithmetic average of RRS +10

*Ave. means the arithmetic average of RRS in the interval of $0.4 \mathrm{sec}$ to $2.0 \mathrm{sec}$ by Eq. (4)

${ }^{* *} F_{v}=$ Ave. +1 standard deviation. 


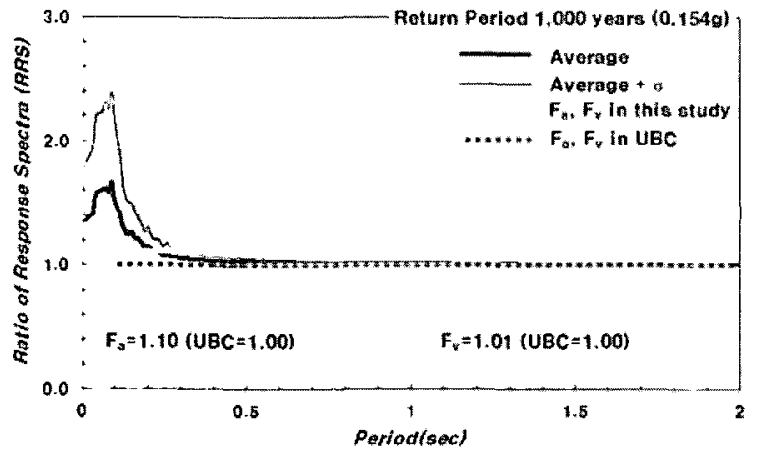

(a) Soil Type $S_{B}$

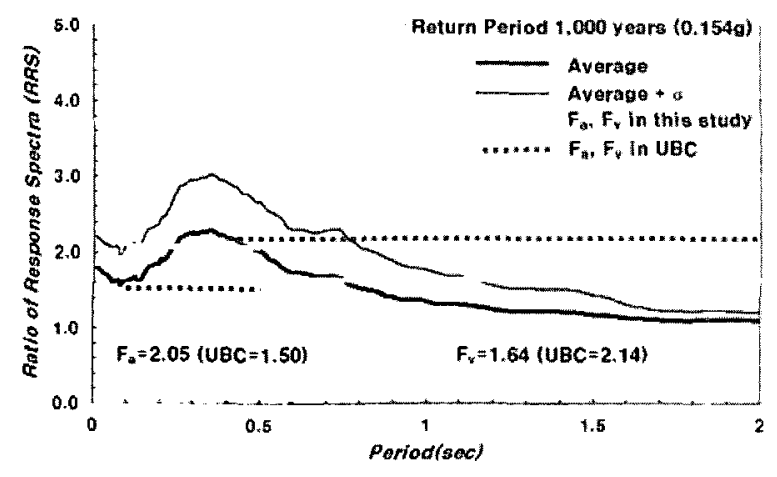

(c) Soil Type $S_{D}$

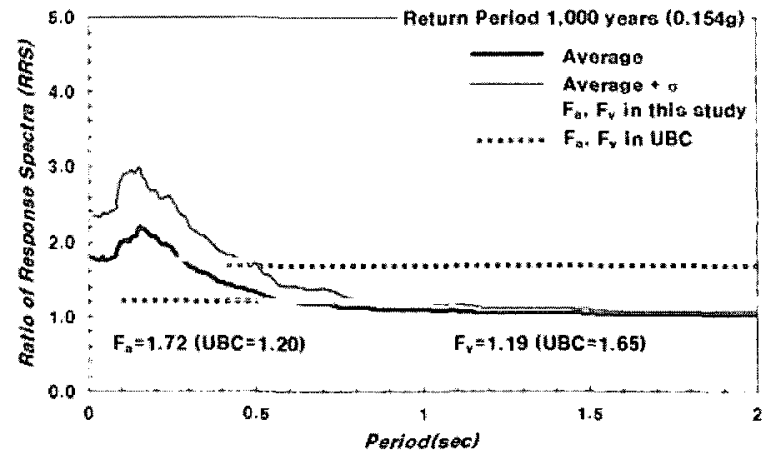

(b) Soil Type $S_{C}$

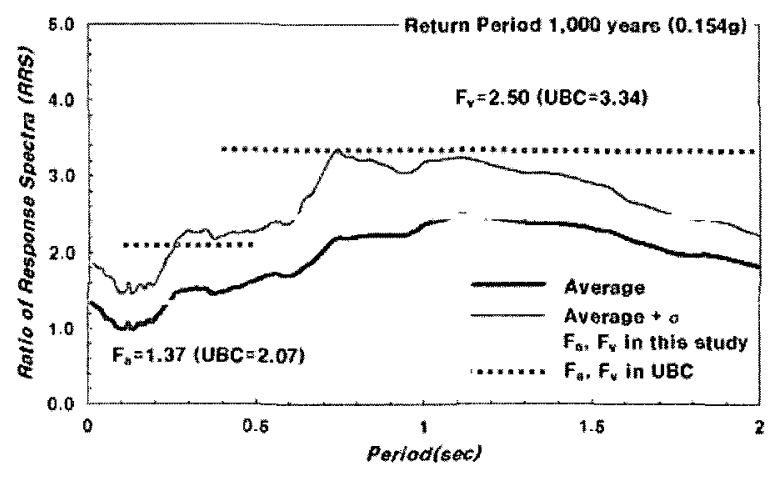

(d) Soil Type $S_{E}$

(Figure 6) Site coefficients evaluated in this study for return period 1,000 years.

\section{NEW SITE CLASSIFICATION BASED ON SITE PERIOD}

In general, site period and shear wave velocity are the most important factors influencing the site response analysis. For example, spectral accelerations from this study were significantly amplified near the site periods as shown in Fig. 5. The fundamental site period that is computed by using equation (2) is a function of thickness and shear wave velocities of soil layers above bedrock. As mentioned earlier, most of the site investigations are performed to the bedrock and shear wave velocity is clearly measurable up to the bedrock by geophysical techniques in the region of shallow bedrock depth. One of the reasons of site classification based on $V_{S 30}$ is that it is practical to use in the region of deep bedrock depth. In the region of shallow bedrock depth, therefore, it is meaningful to consider other site classification system instead of $V_{S 30}$. Site period is the most reasonable candidate, in that it is a function of two important factors, bedrock depth and shear wave velocity profile of the site, influencing on site response analysis and the two factors can be considered as a single factor.

\subsection{Site coefficients based on Site Periods}

As discussed in the previous chapter, the trend line of $\mathrm{S}_{\mathrm{E}}$ sites was clearly different from that of other sites because of soil nonlinearity and different site characteristics, especially for short-period ranges. Therefore, it is convenient to consider $\mathrm{S}_{\mathrm{E}}$ sites separately from other site classes. The probabilistic distributions of site periods for $S_{B}, S_{C}$ and $S_{D}$ were illustrated in Fig. 7 excluding $S_{E}$ sites. It was assumed that the site periods follow the Gaussian distribution function and mean value is 0.287 $\mathrm{sec}$ and the standard deviation is $0.105 \mathrm{sec}$. Mean $-2 \sigma$ is $0.077 \mathrm{sec}$ and mean $+2 \sigma$ is $0.497 \mathrm{sec}$, which the interval of mean $\pm 2 \sigma$ is almost same as the confidence interval of 95 percent limit. Thus, the borders of site period for site classification can be determined as 0.10 $\mathrm{sec}, 0.30 \mathrm{sec}$ and $0.50 \mathrm{sec}$ by rounding off for the simplification.

Variations in site coefficients $F_{a}$ and $F_{v}$ with site 


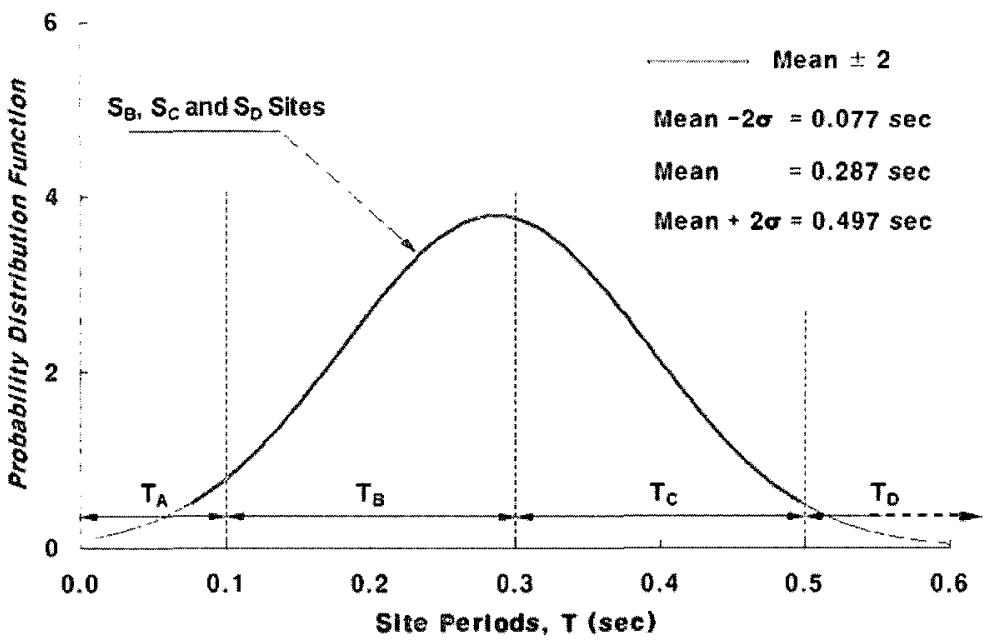

(Figura 7) Probability distribution function of the $S_{B}, S_{C}$ and $S_{D}$ sites with Site Periods

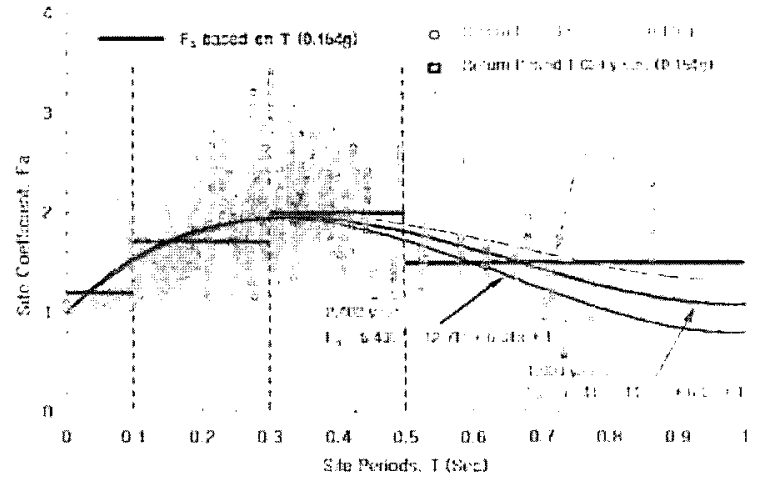

(a) Short Period Site Coefficient, $F_{a}$

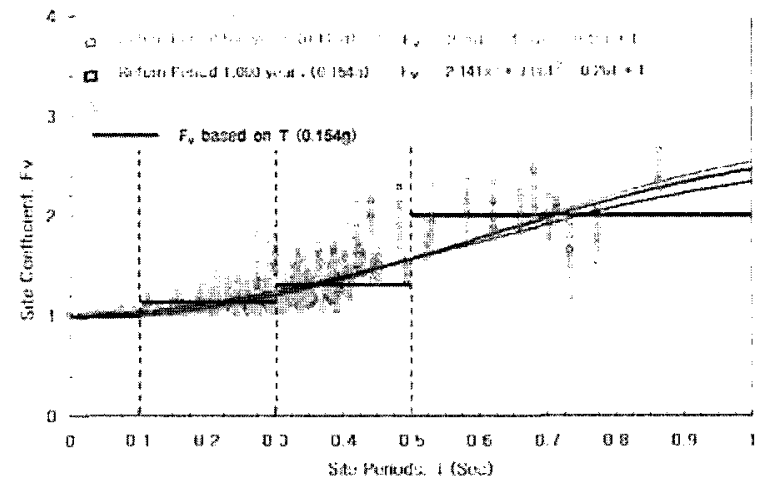

(b) Long Period Site Coefficient, $F_{v}$

〈ifigure 8 ) Site coefficients, $F_{a}$ and $F_{v}$ with Site Periods, $T$

periods were plotted in Fig. 8 to assess their correlations. $F_{a}$ values merged toward 1.0 in the range of $T<0.1 \mathrm{sec}$, increase in $0.1 \mathrm{sec} \leq \mathrm{T} \leq 0.3 \mathrm{sec}$, decrease slowly in $0.3 \mathrm{sec}<\mathrm{T} \leq 0.5 \mathrm{sec}$ and decrease in $0.5 \mathrm{sec}<\mathrm{T}$. The regression curves can be evaluated by third-order polynomial because the curves need minimum two inflection points. The regression curves for $F_{v}$ were also evaluated by third-order polynomial to keep up with those of $F_{a}$.

The regression curves of $F_{a}$ in Fig. 8-(a), are almost identical independent of the return periods in the range of site periods up to $0.30 \mathrm{sec}$, but above $0.30 \mathrm{sec}$ the curves are getting separated with return period. In the long-period range, the regression curve for return period 2,400 years has the lowest value, caused by effect of soil nonlinearity. Whereas, the regression curves of $F_{v}$ in Fig. 8 -(b), three regression curves are almost identical up to $0.60 \mathrm{sec}$, and getting slightly separated in the very long-period range. Therefore, it can be mentioned that there is little effects on site coefficients $F_{a}$ and $F_{v}$ by soil nonlinearity in the short-period sites less than $0.5 \mathrm{sec}$, which are main site period ranges of the Korean Peninsula as shown in Fig. 4.

Based on statistics of site periods, site classes are divided into four groups as follows:

(1) Site Class $T_{A}: T<0.10 \mathrm{sec}$

(2) Site Class $T_{B}: 0.10 \mathrm{sec} \leq \mathrm{T} \leq 0.30 \mathrm{sec}$

(3) Site Class $T_{C}: 0.30 \mathrm{sec}<T \leq 0.50 \mathrm{sec}$

(4) Site Class $T_{D}: 0.50 \mathrm{sec}<\mathrm{T}$

The corresponding values of $F_{a}$ and $F_{v}$ calculated by equations (3) and (4) are listed in Table 6 and Table 7. The values of $F_{a}$ and $F_{v}$ based on $V_{S 30}$ of $S_{B}, S_{C}, S_{D}$ and $\mathrm{S}_{\mathrm{E}}$ sites were also listed in Table 4 and Table 5.

It is interesting to note that calculated values of $F_{a}$ and $F_{\mathrm{v}}$ based on the site period and $V_{\mathrm{S} 30}$ are almost equal 
〈Table 6) Site Coefficients for short-period $F_{a}$ based on Site Period

\begin{tabular}{c|c|c|c|c|c|c|c}
\hline \multirow{2}{*}{ Site Period $\mathrm{T}(\mathrm{sec})$} & \multicolumn{2}{c|}{$0.110 \mathrm{~g}$} & \multicolumn{2}{c}{$0.154 \mathrm{~g}$} & \multicolumn{2}{c}{$0.220 \mathrm{~g}$} \\
\cline { 3 - 8 } \multicolumn{2}{l|}{} & Average & $\sigma$ & Average & $\sigma$ & Average & $\sigma$ \\
\hline $\mathrm{T}<0.1$ & $\mathrm{~T}_{\mathrm{A}}$ & 1.19 & 0.273 & 1.20 & 0.297 & 1.22 & 0.319 \\
\hline $0.1 \leq \mathrm{T} \leq 0.3$ & $\mathrm{~T}_{\mathrm{B}}$ & 1.73 & 0.401 & 1.73 & 0.411 & 1.80 & 0.446 \\
\hline $0.3<\mathrm{T} \leq 0.5$ & $\mathrm{~T}_{\mathrm{C}}$ & 2.05 & 0.431 & 2.02 & 0.418 & 1.96 & 0.448 \\
\hline $0.5<\mathrm{T}$ & $\mathrm{T}_{\mathrm{D}}$ & 1.62 & 0.502 & 1.49 & 0.512 & 1.39 & 0.522 \\
\hline
\end{tabular}

$\left\langle\right.$ Table 7〉 Site Coefficients for long-period $F_{v}$ of arithmetic average of RRS +10 based on Site Period

\begin{tabular}{|c|c|c|c|c|c|c|c|c|c|c|}
\hline \multirow{2}{*}{\multicolumn{2}{|c|}{ Site Period T $(\mathrm{sec})$}} & \multicolumn{3}{|c|}{$0.110 \mathrm{~g}$} & \multicolumn{3}{|c|}{$0.154 \mathrm{~g}$} & \multicolumn{3}{|c|}{$0.220 \mathrm{~g}$} \\
\hline & & Ave. & $\sigma$ & $F_{v}$ & Ave. & $\sigma$ & $F_{\mathrm{v}}$ & Ave. & $\sigma$ & $\overline{F_{v}}$ \\
\hline $\mathbf{T}<0.1$ & $\mathrm{~T}_{\mathrm{A}}$ & 1.01 & 0.016 & 1.03 & 1.01 & 0.018 & 1.03 & 1.01 & 0.021 & 1.04 \\
\hline $0.1 \leq \mathrm{T} \leq 0.3$ & $\mathrm{~T}_{\mathrm{B}}$ & 1.09 & 0.083 & 1.18 & 1.11 & 0.096 & 1.20 & 1.13 & 0.123 & 1.25 \\
\hline $0.3<\mathrm{T} \leq 0.5$ & $\mathrm{~T}_{\mathrm{C}}$ & 1.28 & 0.227 & 1.51 & 1.31 & 0.240 & 1.55 & 1.34 & 0.233 & 1.58 \\
\hline $0.5<\mathrm{T}$ & $\mathrm{T}_{\mathrm{D}}$ & 2.02 & 0.427 & 2.45 & 1.99 & 0.418 & 2.41 & 1.94 & 0.437 & 2.37 \\
\hline
\end{tabular}

with a little difference in the standard variations except for $F_{a}$ values of site class $S_{B}$ and $T_{A}$ although the criteria of site classification is entirely different. Among the 76 sites of $\mathrm{S}_{\mathrm{C}}$ based on $\mathrm{V}_{\mathrm{S} 30}, 24$ sites were moved to Site Class $T_{A}$ or $T_{C}$ based on site periods. And among the 60 sites of $S_{D}$ based on $V_{S 30}, 22$ sites were moved to Site Class $T_{A}, T_{B}$ or $T_{D}$ based on site periods. Those are up to 31 percent and 37 percent of the original members, respectively. Thus, it is interesting results that the site coefficients were not changed as much as the site members were changed.

Site coefficients based on site periods and $V_{\mathrm{S} 30}$ are both scattered wide as shown in Fig. 7, especially in the short-period range. The local site conditions such as bedrock depth are quite various because the shear wave velocity profiles are collected around the Korean Peninsula. Furthermore, the frequency contents of input earthquake motions are also various, thus it is not surprised that the calculated values of $F_{a}$ and $F_{v}$ are scattered wide. It is difficult to say that one of the classification methods, either based on site period or $\mathrm{V}_{\mathrm{S} 30}$, is superior when considering the standard deviations as listed in Table 4 through Table 7. However, site classification based on site period is recommended if the bedrock depth and shear wave velocities are clearly defined because site period is a function of bedrock depth and shear wave velocity profile which are the most important factors influencing on site response results and it also removes the fallaciousness by extrapolating the $V_{S}$ of bedrock to $30 \mathrm{~m}$ in the region of shallower bedrock depth.

\subsection{Response Spectrum based on Site Period}

The average response spectra for site classes based on site period together with those based on $V_{S 30}$ were plotted for return period 1,000 years (rock-outcrop motion $=0.154 \mathrm{~g}$ ) in Fig. 10 . It can be noticed that both spectra are similar as expected because the estimated site coefficients based on site period and $\mathrm{V}_{\mathrm{S} 30}$ listed in Table 4 through Table 7 are almost equal. Therefore, in the following descriptions, the average response spectrum for site classes based on site period were compared to the spectrum in the current Korean code, and new design spectrum based on site coefficients in Table 6 and Table 7 are proposed.

In the case of site class $T_{A}$, short-period site coefficient $F_{a}$ is slightly larger than that of $S_{B}$ site, thus the proposed response spectrum is also larger than current code. The average spectral accelerations up to $0.2 \mathrm{sec}$ are still higher than the proposed response spectrum, but spectral accelerations are sufficiently lower than the proposed response spectrum at periods above $0.2 \mathrm{sec}$ as shown in Fig. 9-(a). The new spectrum is similar to current code spectrum at $S_{B}$ sites except short periods. Thus, it is hard to say that new response spectrum of $T_{A}$ class is improved compared with that of $S_{B}$ sites, but two spectrums satisfy the objective of site classification. 


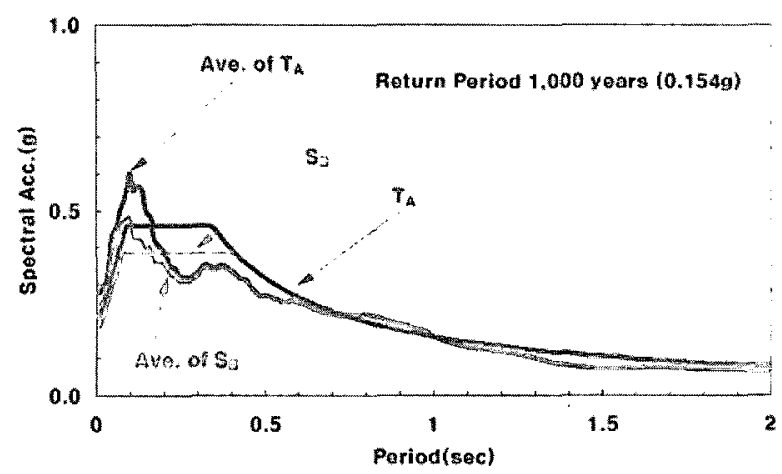

(a) Site Class $T_{A}$

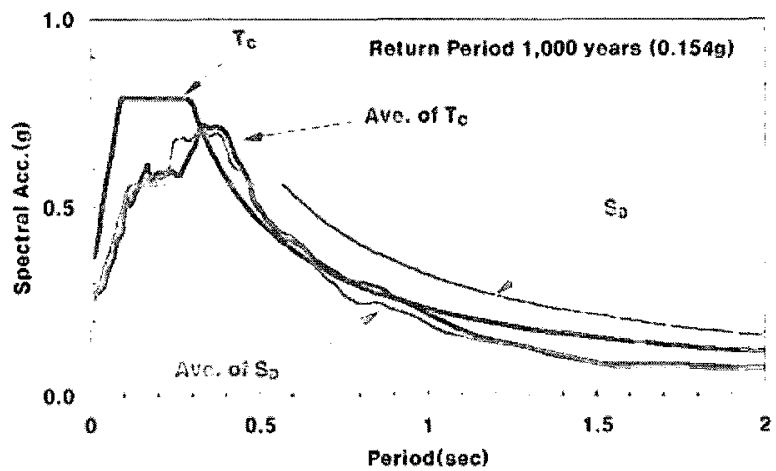

(c) Site Class $T_{c}$

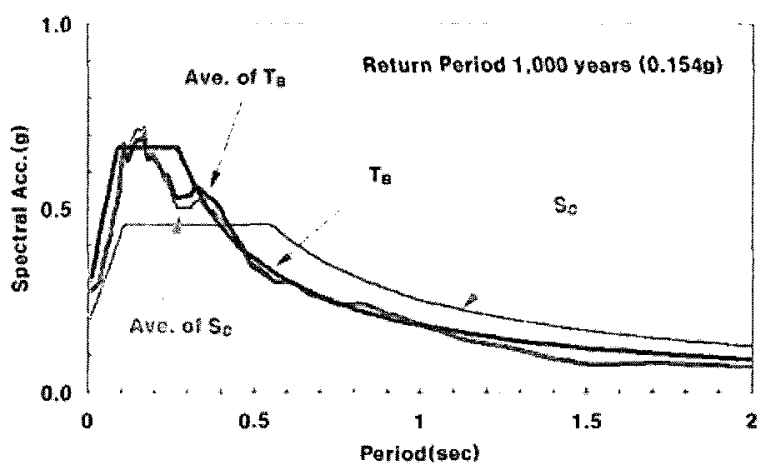

(b) Site Class $T_{B}$

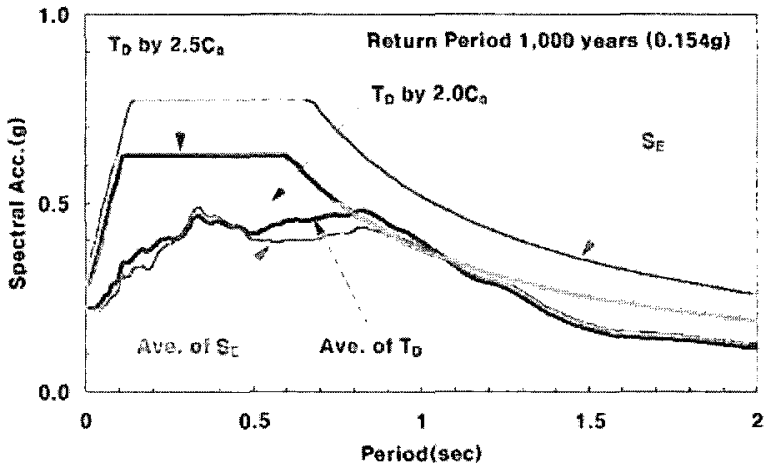

(d) Site Class $T_{0}$

(Figure 9) Evaluated Response Spectra based on Site Period for Return Period 1,000 years.

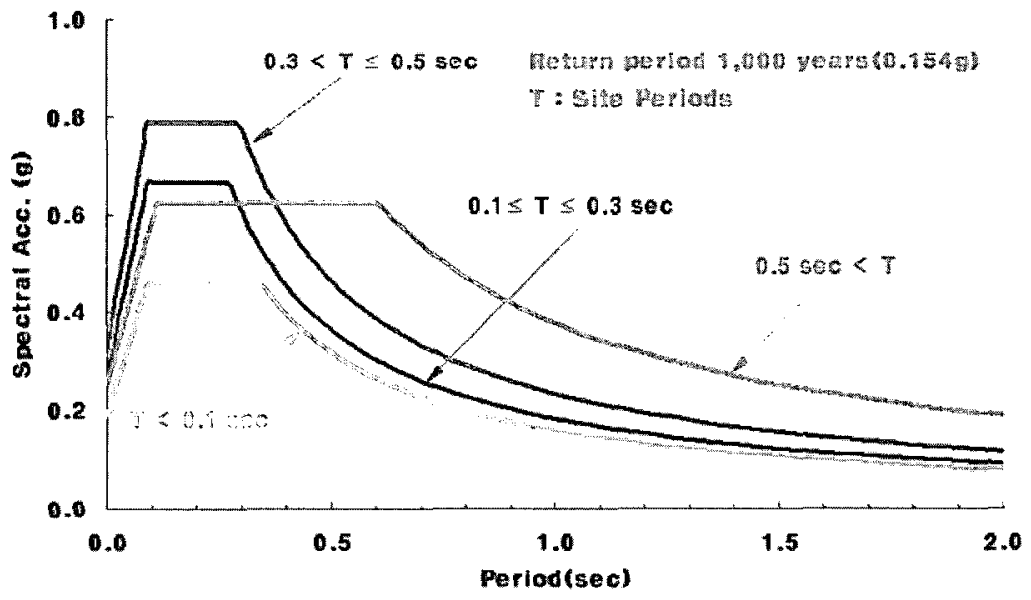

〈iigure 10) Response Spectra based on Site Period T for Return Period 1,000 years.

In the case of site class $T_{B}$ in Fig. 9-(b), new response spectrum matches well with the average spectral accelerations in the whole period ranges. It is interesting to note that the average response spectrum of $T_{B}$ sites also matches well with the average spectral accelerations of $\mathrm{S}_{\mathrm{C}}$ sites even through 30 percent of sites are changed as mentioned earlier. Although the site members of the two methods are different, it can be concluded that response spectrum is improved for site class $T_{B}$, rather than $S_{C}$ sites, in that it matches well with the average spectrum.

In the case of site class $T_{C}$ in Fig. 9-(c), new response spectrum does not match well the average spectral acceleration in the period ranges $0.30-0.50 \mathrm{sec}$, which is the main site period range of site class $T_{C}$. Even though the new spectrum will be required to be modified by adjusting the interval of integration in equation (4), it can be noticed that new response spectrum of site class $T_{C}$ is improved compared to the code spectrum for $S_{D}$ 
site based on $\mathrm{V}_{\mathrm{S} 30}$.

The new response spectrum of site class $T_{D}$ is larger than the average spectral accelerations in the period ranges up to $0.9 \mathrm{sec}$ and the code spectrum of $S_{E}$ is much larger than the average spectral accelerations in the whole period ranges as indicated in Fig. 9-(d). The response spectrum of site class $T_{D}$ was determined based on the Korean code. The plateau value in short-period ranges is 2.5 times of the ground acceleration $\left(\mathrm{C}_{\mathrm{a}}\right)$. However, spectral acceleration of $T_{D}$ site is less amplified in the short-period ranges than the code spectrum and there are clearly differences between the spectral accelerations in the site class $T_{D}$ and the code values. It may be due to the soil nonlinearity and if the plateau value in short-period ranges is determined by 2.0 times of the ground acceleration $\left(\mathrm{C}_{\mathrm{a}}\right)$, the average spectral accelerations and response spectrum of $T_{D}$ match well as indicated in Fig. 9-(d).

New response spectra for four site classes for return period 1,000 years are plotted together in Fig. 10. Spectral shapes in site classes $T_{A}, T_{B}$ and $T_{C}$ are similar but clear difference can be noticed in spectral shape for site class $T_{D}$, owing to the differences of site characteristics.

\section{CONCLUSIONS}

To evaluate the earthquake ground motions in Korea, shear wave velocity profiles are collected at 162 sites. Based on the ground response analyses the following conclusions are obtained;

Owing to the differences in geological site conditions, particularly the site periods and bedrock depth between Korea and western United States, site classification method in the current Korean seismic guideline is required to be modified considering site characteristics of Korea.

For the site classes $S_{C}$ and $S_{D}$, the site coefficients of short-period $\left(F_{a}\right)$ and the long-period $\left(F_{v}\right)$ obtained from this study are significantly different compared to the current seismic code. $F_{a}$ underestimates the motion in short-period ranges and $F_{v}$ overestimates the motion in mid-period ranges in Korean seismic guideline. It is found that the existing Korean seismic design guideline is required to be modified considering geological site conditions in Korea for the reliable estimation of site amplification.

New regression curves were derived between site coefficients $\left(F_{a}\right.$ and $\left.F_{v}\right)$ and the fundamental site periods, and site coefficients were grouped based on site periods the with reasonable standard deviations compared to site classification based on $\mathrm{V}_{\mathrm{S} 30}$.

New site classification system and site coefficients $\left(F_{a}\right.$ and $F_{v}$ ) were suggested based on site period and the design response spectrum for 4 site classes were tentatively proposed. It was found that new site classification based on site period can be a feasible alternative instead of using $V_{\mathrm{S} 30}$ in the regions of shallow bedrock.

\section{REFERENCES}

1. NEHRP, "Recommended Provisions for Seismic Regulation for New Buildings," FEMA 222A/223A, May, Vol. 1 (Provisions) and Vol. 2 (Commentary), 1994.

2. NEHRP, "Recommended Provisions for Seismic Regulation for New Buildings and Other Structures," FEMA 302/303, February, Part I. (Provisions) and Part. 2 (Commentary), 1997.

3. ICBO, "1997 Uniform building code," Volume 2 - Structural engineering design provisions, International Conference of Building Officials, 1997, pp. 492.

4. CEN (Comite Europeen de Normalisaton), "prEN 1998-1Eurocode 8: Design of Structures for Earthquake Resistance Part I : General Rule, seismic actions and rules for buildings," DRAFT No 3, Doc CEN/TC250/SC8/N288, May 2001, Brussels.

5. Ministry of Construction and Transportation (MOCT). Seismic Design Guide, 1997.

6. MCEER-99-0010, "Site Factors and Site Categories in Seismic Codes", Ricardo Dobry, Ricardo Ramos and Maurice S, Power. July 19, 1999.

7. Bardet, J.P., Nielsen, E., Villacorta, R., 1998. ROSRINE data dissemination. http://geoinfo.usc.edu/rosrine. Accessed 12 June 2001.

8. Sun, C.G., "Geotechnical information system and site amplification characteristics for earthquake ground motions at inland of the Korean Peninsula". Ph. D. Dissertation, Seoul Nation University. Feb. 2004.

9. Schnabel, P. B., Lysmer, J., and Seed, H. B (1972), "SHAKE: a computer program for earthquake response analysis of horizontally layered sites," Report EERC 72-12, Earthquake Engineering Research Center, University of California, Berkeley. 
10. Idriss, I. M., and Sun, J, I. User's manual for SHAKE91: A computer program for conducting equivalent linear seismic response analysis of horizontally layered soil deposits, University of California, Davis, 1992, 13pp http://peer.berkeley.edu/smcat/search.html

11. D.S.Kim and Y.W. Choo, "Dynamic Deformation Characteristics of Cohesionless Soils in Korea Using Resonant Column Tests", Journal of Korean Geotechnical Society. Vol. 17,
No. 5, 2001, pp. 115-128.

12. Dobry, R. et, al. "Development of Site-Dependent Ratio of Elastic Response Spectra (RRS)", Proceeding of the Workshop on Earthquake Site Response and Seismic Code Provisions, 1999.

13. Roger D. Borcherdt, "Emperical Evidence for Site Coefficients in Building Code Provisions", Earthquake Spectra, Volume 18. No. 2, May 2002, pp. 189-217. 